ST. MARY'S HOSPITALS, MANCHESTER, 1790-1963

By J. H. YOUNG, M.D., D.(OBST.)R.C.o.G.

132 pages.

32 illustrations.

30 s.

THE OTAGO MEDICAL SCHOOL UNDER THE FIRST THREE DEANS

BY SIR CHARLES HERCUS and SIR GORDON BELL.

390 pages.

37 illustrations.

45s.

\title{
THE ANATOMICAL LECTURES OF WILLIAM HARVEY
}

The Prelectiones Anatomie Universalis and De Musculis

Edited, with an introduction, translation and notes by GWENETH WHITTERIDGE, M.A., D.PHIL., F.S.A.

568 pages.

7 plates.

£7 7s. 0 d.

\section{E. \& S. LIVINGSTONE, LTD., TEVIOT PLACE, EDINBURGH}

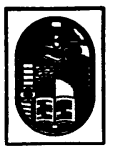

John Wright \& Sons Ltd Bristol

Just Published

\section{THE STORY OF THE} PROGRESS OF MEDICINE

by Charles F. V. Smout

This book will appeal to all adult readers. The method of presenting the facts of medical progress through the ages up to the present day, is exciting and memorable and forms a coherent, entertaining, and scholarly narrative. The bibliography provides an excellent basis for further study of the many works on the subject. 164 pages $5 \frac{3}{4} \times 9$ in. 48 illustrations

Price 30s., post $1 \mathrm{~s}$.
Books on the History of Medicine and Dentistry Rare Books $\star$

We purchase collections We send lists

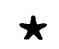

RITTENHOUSE BOOK STORE

1706 Rittenhouse Square, Philadelphia 3, Pennsylvania Kingsley 5-4274 


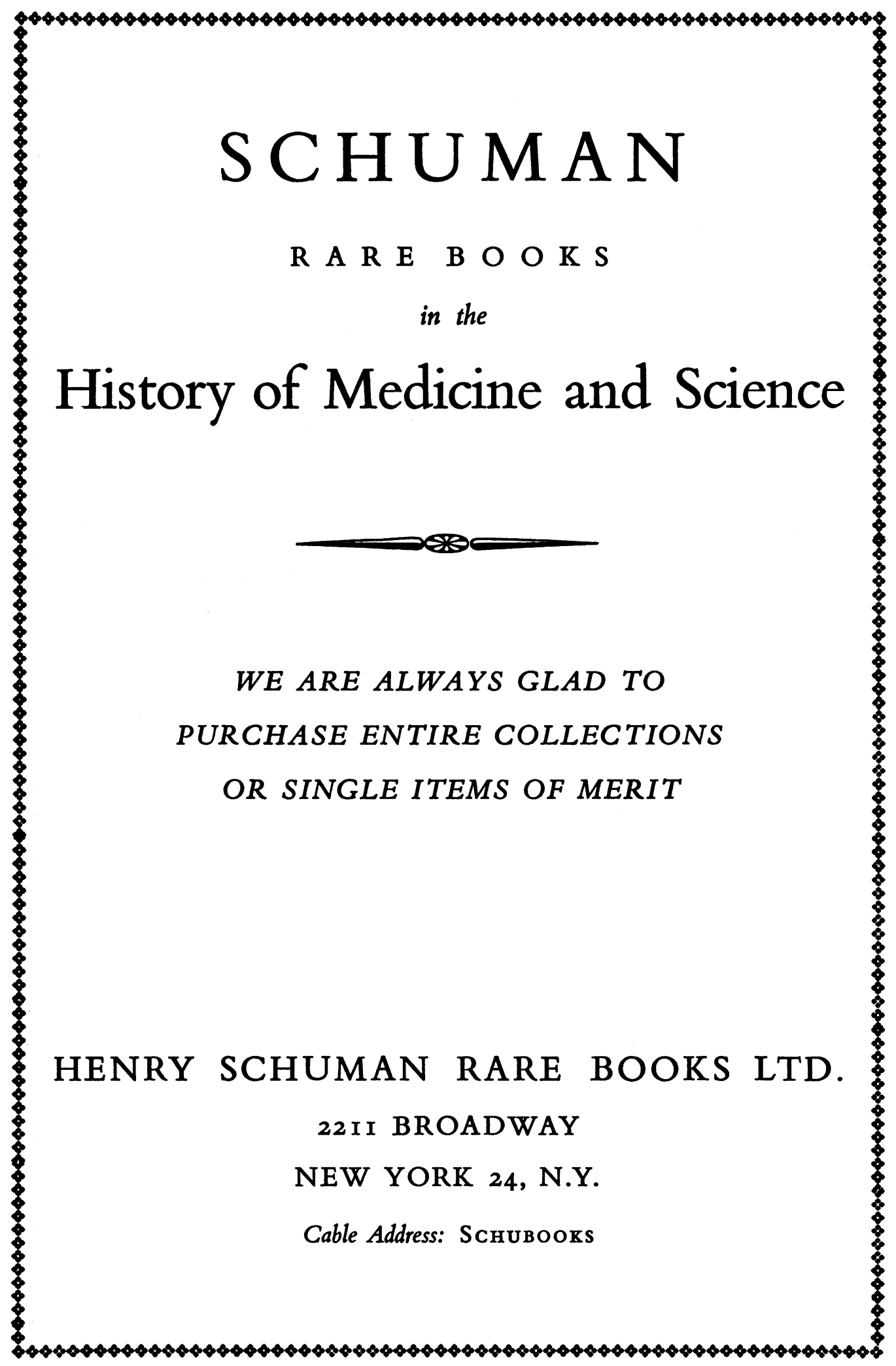




\section{announcing a new book! .}

\section{PHARMACY IN HISTORY}

by Professor G. E. TREASE, B.Pharm., D. de l'U., F.P.S., F.R.I.C., F.L.S., Professor of Pharmacognosy, and Head of the Department of Pharmacy, University of Nottingham

Professor Trease's interesting and stimulating new book spans the centuries and brings into focus the growth of pharmacy through the ages. It is an important contribution to the history of medicine as a whole.

Professor Trease first deals briefly with our inheritance from the Ancient Civilizations and then follows the development of English Pharmacy up to the present day. The foundation of the Pharmaceutical Society and the history and growth of some of the famous drug houses of today are among the subjects described in the later chapters.

Sufficient general and social history has been introduced to enable the reader to visualize some of the general changes which were taking place during each period of pharmaceutical evolution.

Pharmacy in History presents an attractive and well-illustrated account of a fascinating subject.

272 pages.

51 illustrations.

50 s.

\section{BAILLIERE, TINDALL \& COX}

7 \& 8 Henrietta Street, London, W.C.2 


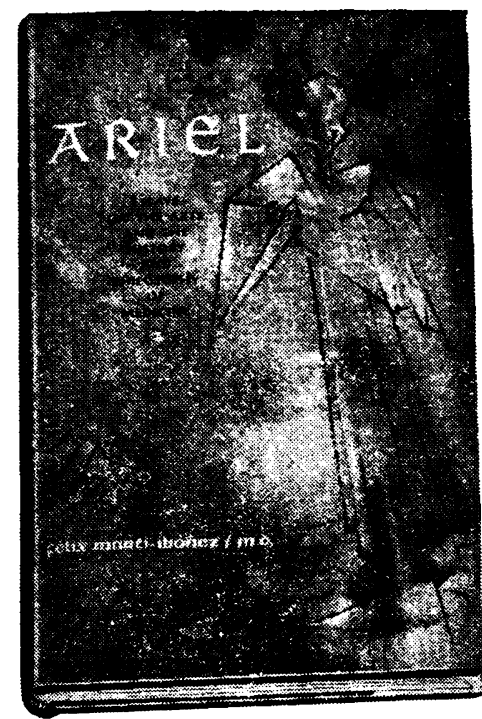

Partial Table of Contents

I. THROUGH THE MAGIC DOOR OF WORDS / The

Fabric and Creation of a Dream - More Magic in Words - Friends for the Road - No Books on the Ferry from Hong Kong • Tell Me a Story

II. THE WONDER-WORLD

OF SYMBOLS / Symbols and

Medicine - On An Armenian

"Flying Carpet"

III. THE MARCH OF

MEDICAL HISTORY / The

Great Historical Challenges in Medicine ."That Skill That Death

Loves Not" • and others

IV.THE EPIC OF MEDICINE

V. JOURNEYS, PORTS,

PEOPLES / The Family of Man

- Vast and Wide Is the World

- The Restless Emerald - The

Chase of the Butterfly . Those

Glittering Towers $\cdot$ and others

VI. LOVE, LUST, AND

LETTERS / Ars Amandi

- Casanova, Then and Now

- A Letter from Madame

VII. THE MARVELS OF

MAN / The Mask and the

Mirror - The Miracle Tool

- The Eye and the Glance

VIII. THE PHILOSOPHY OF

MEDICINE / Doctors Must

Tell $\cdot$ Man, as Nature and as

History

IX. RELIGIO MEDICI

To Be a Doctor - The Young

Princes - The Legacy of St. Luke INDEX

\section{a new reading adventure} in medicine and the arts

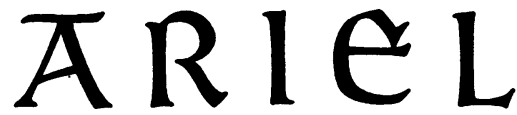

ESSAYS ON THE ARTS AND THE HISTORY AND PHILOSOPHY OF MEDICINE

\author{
by FELIX MARTI-IBANEEZ, M.D.
}

Editor-in-Chief of the Medical Newsmagazine, $M D$;

Former Professor and Chairman, Department of the

History of Medicine, New York Medical College

This

his new collection of articles and essays traverses the vast expanse of human experience to present a fresh and exciting view of the world of medicine and the arts. ARIEL: ESSAYS ON THE ARTS AND THE HISTORY AND PHILOSOPHY OF MEDICINE combines new concepts, original observations, and imaginative thinking in a book that will give many hours of reading pleasure. One of the outstanding features of this collection of 42 essays and articles is the inclusion of the author's 13 original expanded versions of his introductions to the installments of THE EPIC OF MEDICINE, which originally appeared in the medical newsmagazine, $M D$. As a unit they provide a dramatic and cogent preface to the history of medicine. The other essays and articles in this volume cover a wide range of both historical and contemporary subjects.

ARIEL is a book for those who choose to explore the wondrous paths of the human mind. It is a book for physicians, philosophers, sociologists, educators, students-all who know the excitement of discovery and seek new ideas.

292 PAGES/CLOTH BOUND/ $\$ 6.50$

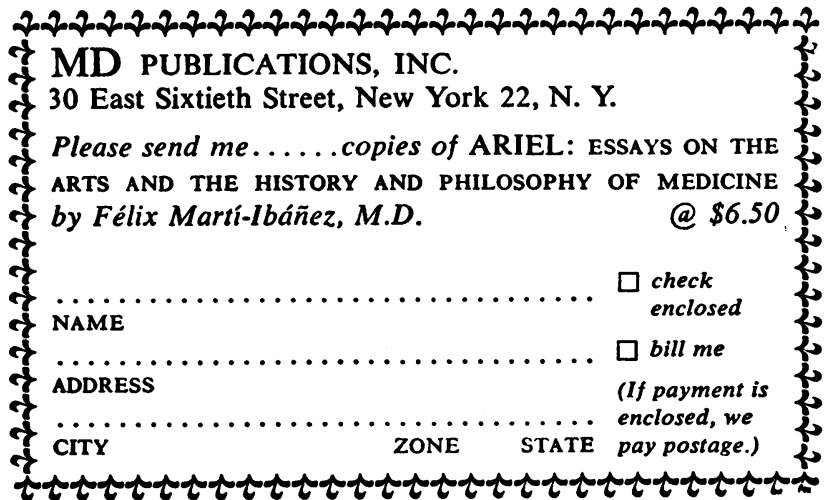

\section{PUBLICATIONS, INC. / NEW YORK}




\section{Medical Books}

\section{Prints Manuscripts Portraits}

Old, Rare, \& OUt-of-Print America's Largest Stock

A vast stock, fully catalogued and classified, American and European, dating from $X V-X X$ Centuries, particularly classical and unusual works, with emphasis upon history, biography, and specialized medicine. Lists issued in all fields of medicine. Permanent back-order files maintained.

\section{ARGOSY BOOK STORES}

114 E. 59th St., N.Y. 22, N.Y. PL 3-4455

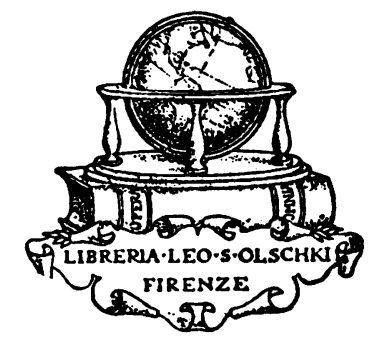

\section{LEO S. OLSCHKI}

We have a large stock of antiquarian MEDICAL AND SCIENTIFIC BOOKS. Our MODERN BOOK DEPARTMENT can also supply all current Italian books and periodicals.

Catalogues sent on application.

Lungarno Guicciardini

FIRENZE - ITALY

\section{DAWSONS OF PALL MALL}

New titles now available

STARLING ON THE HEART

Facsimile reprints, including the Linacre Lecture on the Law of the Heart. Analysis and Critical Comment by

CARLETON B. CHAPMAN, M.A., M.D., and JERE H. MITCHELL, B.S., M.D. 214 pp. (78 pp. text, 136 pp. facs.), 10 illus., cloth.

\section{ATHEROSCLEROSIS IN AN AUTOPSY SERIES}

JOHAN CHR. GIERTSEN.

141 pp., 72 tables, 30 figs., Oslo U.P.

TREATMENT FOR TUBERCULOSIS OF THE SPINE BERNHARD PAUS.

139 pp., figs., tables, Oslo U.P.

SHIFT WORK AND HEALTH

ANTHON AANONSEN.

91 pp., figs., tables, Oslo U.P.

CORTISOL IN THE NEW BORN INFANT DAGFINN AARSKOG.

91 pp., figs., tables, Oslo U.P. 